\title{
An update of Wnt signalling in endometrial cancer and its potential as a therapeutic target
}

\author{
A Coopes*, C E Henry*, E Llamosas and C E Ford
}

Gynaecological Cancer Research Group, Lowy Cancer Research Centre and School of Women's and Children's Health, Faculty of Medicine, University of New South Wales, Sydney, New South Wales, Australia

Correspondence should be addressed to C E Ford: caroline.ford@unsw.edu.au

*(A Coopes and C E Henry contributed equally to this work)

\begin{abstract}
Endometrial cancer is the most common gynaecological malignancy in developed nations, and its prevalence is rising as women defer or decide not to have children and as obesity rises, both key risk factors. Despite this, treatment options remain limited, particularly for advanced or refractory disease. New genomic analyses have revealed distinct mutational profiles with therapeutic and prognostic potential. Wnt signalling, which is pivotal in embryogenesis, healing and homeostasis, is of importance in the endometrium and has been linked to carcinogenesis. This review aims to update and discuss the current evidence for the role of $\beta$-catenin dependent and independent Wnt signalling, including the ROR receptors in the endometrium and its potential as a therapeutic target, in light of recent trials of Wnt-targeted therapy in multiple tumour types.
\end{abstract}

\author{
Key Words \\ - endometrial cancer \\ - uterine cancer \\ -Wnt signalling
}

\section{Introduction}

Endometrial cancer is the most common gynaecological malignancy in the developed world, with an estimated 320,000 new cases diagnosed globally each year. It is the fourth most prevalent cancer after neoplasms of the breast, colorectum and lung among women in the West, and incidence is rising due to a combination of increased awareness and detection, population ageing and acceleration in risk factors including obesity and nulliparity (Ferlay et al. 2015). Endometrial cancer is also increasingly fatal, with mortality rising by $2.1 \%$ annually between 2008 and 2014 in the United States, principally attributed to the growing obesity burden. Worldwide, the mortality rate remains in excess of $20 \%$ (Ferlay et al. 2015).

A number of aetiological factors can increase the risk of endometrial cancer, including age, parity, oral contraceptive pill use, age at menarche and type two diabetes mellitus (Brinton et al. 2013). Prolonged exposure to unopposed oestrogens is the single most important risk factor for developing endometrial cancer, particularly type one tumours (described below), and polycystic ovarian syndrome, early menarche and late menopause, anovulatory or erratic periods, use of oestrogen-only hormone replacement therapy, oral contraceptive pills or tamoxifen and nulliparity are all implicated (Grady et al. 1995, McPherson et al. 1996, Allen et al. 2008, Group et al . 2014a).

A number of previous reviews have discussed signalling pathways involved in homeostasis of the endometrium and various pathologies, and two recent reviews have examined Wnt inhibitors in pre-clinical settings but with limited discussion of implications for endometrial cancer (Eritja et al. 2017, Katoh \& Katoh 2017). Previous reviews have focused on $\beta$-catenin-dependent Wnt signalling with no discussion of the $\beta$-catenin-independent receptors 
ROR1 and ROR2 (Wang et al. 2009, Markowska et al. 2014, Kiewisz et al. 2015, Eritja et al. 2017, Katoh \& Katoh 2017). Therefore, here we provide an updated discussion on possible avenues and challenges for targeted Wnt treatment in molecular and histological subtypes of endometrial cancer.

\section{Classification}

Historically, endometrial cancer was classified into two distinct subtypes known as Bokhman type one and type two (Bokhman 1983). Type one tumours originally included the endometrioid histological subtype of all grades, a class typically driven by obesity and related hormonal imbalances. These tumours account for approximately $90 \%$ of all endometrial cancers and are usually diagnosed early with good prognosis. Type two tumours included other non-endometrioid histological subtypes such as serous and clear cell and have propensity for myometrial invasion, metastasis and recurrence.

More recently, The Cancer Genome Atlas (TCGA) and others have integrated genomic, transcriptomic and proteomic analyses on large tumour cohorts to identify new molecular classification signatures with prognostic and therapeutic utility (Byron et al. 2012, McConechy et al. 2012, Talhouk et al. 2015). The TCGA consortium identified four discrete subtypes of endometrial cancer based on mutation profile and major genetic alterations: POLE, Microsatellite Instability (MSI), Copy Number Low (CN Low) and Copy Number High (CN High), as detailed in Table 1 . The Bokhman classification does not fully align with these molecular subtypes. Underscoring the limitations of the dual classification model, the TCGA identified aggressive markers in some histologically indolent lesions (type one) or a favourable genomic profile in other tumours assessed as having a poor outlook (type two) (Levine \& The Cancer Genome Atlas Research Network 2013). One in four high-grade endometrioid endometrial cancers examined by the TCGA were reclassified from Bokhman type one to type two cancers on molecular analysis (McConechy et al. 2012, Church et al. 2013, Meng et al. 2014, Murali et al. 2014, Hussein et al. 2015, Talhouk et al. 2015). Tumourinfiltrating lymphocytes were found to be a hallmark of the POLE and MSI molecular subgroups, making them a potentially attractive target for immunotherapies, while a subset of endometrioid tumours with serous-like copy number alterations may benefit from chemotherapy rather than radiotherapy (Levine \& The Cancer Genome Atlas Research Network 2013).

Genomic tumour analysis has also revealed novel avenues for therapy, targeting common pathways across organ sites. For example, serous endometrial carcinoma shares features with serous ovarian cancer and triplenegative breast cancer, while clear cell ovarian tumours resemble clear cell lesions of the endometrium, suggesting common therapeutic targets (Fadare et al. 2013, Levine \& The Cancer Genome Atlas Research Network 2013, Hoang et al. 2014). By contrast, while endometrioid endometrial carcinomas appear to have a distinct mutation profile compared with endometrioid ovarian tumours, they share genetic features with colorectal carcinomas (McConechy et al. 2012, Levine \& The Cancer Genome Atlas Research Network 2013).

\section{Treatment}

Though considered a relatively good prognosis cancer, with 5-year survival of up to $90 \%$ for early stage, lowgrade tumours, as many as $30 \%$ of all endometrial cases

Table 1 Molecular subtypes of endometrial cancer identified by The Cancer Genome Atlas Research Group.

\begin{tabular}{|c|c|c|c|c|c|c|}
\hline Group & Mutation rate/Mb & $\begin{array}{l}\text { Somatic copy } \\
\text { number } \\
\text { alterations }\end{array}$ & Histology & $\begin{array}{l}\text { Bokhman } \\
\text { type }\end{array}$ & Major genetic alterations & Prognosis \\
\hline POLE & $200 \times 10^{6}$ (ultra) & Negligible & $\begin{array}{l}\text { Endometrioid, high } \\
\text { grade }\end{array}$ & T1 & $\begin{array}{l}\text { Similar to CN low } \\
\text { (cellular metabolism) } \\
\text { but with p53 mutations }\end{array}$ & Good \\
\hline MSI & $20 \times 10^{6}$ (hyper) & + & $\begin{array}{l}\text { Endometrioid, } \\
\text { heterogeneous }\end{array}$ & $\mathrm{T} 1$ & MSI (MLH1/Lynch) & Intermediate \\
\hline MSS/CN low & $2 \times 10^{6}$ & ++ & $\begin{array}{l}\text { Endometrioid, low } \\
\text { grade }\end{array}$ & $\mathrm{T} 1$ & $\begin{array}{l}\text { PTEN/PI3K-Akt, KRAS, } \\
\text { ARID1a, CTNNB1++ } \\
(52 \%)\end{array}$ & Intermediate \\
\hline CN high & $2 \times 10^{6}$ & +++ & $\begin{array}{l}\text { Serous, clear cell, } 20 \% \\
\text { high-grade } \\
\text { endometrioid }\end{array}$ & $\mathrm{T} 2$ (and T1) & $\begin{array}{l}\text { P53 (cell cycle } \\
\text { deregulation) }\end{array}$ & Poor \\
\hline
\end{tabular}

CN, copy number; MSI, microsatellite instability; MSS, microsatellite stable; POLE, polymerase epsilon. 
are detected at regional or distant stages, and survival drops off sharply with advancing stage. Prognosis also varies significantly between histological subtypes, with endometrial cancer increasingly understood as representing a heterogeneous spectrum of diseases with divergent, and sometimes overlapping, mechanisms and therapeutic opportunities (Dellinger et al. 2012, AlHilli et al. 2014, Bakkum-Gamez et al. 2014, Rutgers 2015, de Haydu et al. 2016, Mota et al. 2017). Despite this, there have been few changes to the dominant treatment paradigm in recent decades. Recurrence and resistance remain significant challenges, and little is understood about who should receive particular kinds of treatment or how they will respond based on disease profile.

At present, surgery is the mainstay of management typically consisting of hysterectomy and bilateral salpingooophorectomy, with lymph node dissection depending on the extent of disease (Amant et al. 2005, Group et al. $2014 a, b)$. Critically, there are few treatment options for advanced or refractory lesions, with 5-year survival of just 19\% in the context of distant metastases (Obel et al. 2006, Dellinger \& Monk 2009, Bradford et al. 2015). In addition, there is presently no reliable way to differentiate hyperplasia from carcinoma prior to hysterectomy.

Targeted therapies and prognostic markers are lacking for women with endometrial cancer, particularly those with advanced disease. The advent of personalised medicine seen in lung, breast, gastrointestinal and haematological malignancies is yet to reach gynaecological cancers, and improved understanding of the molecular pathways underlying carcinogenesis holds great promise for advancing targeted therapies. Wnt signalling has been shown to have a role in tumorigenesis in all gynaecological organ systems, with the beta-catenin-independent pathway emerging as an exciting area of inquiry.

\section{Wnt signalling}

Wnt signalling is a cellular pathway consisting of an evolutionary conserved family of 19 ligands and 10 receptors. In humans, Wnt signalling is pivotal in embryonic development and tissue homeostasis, with a role in primary axis formation, organogenesis, stem cell proliferation and fate decisions. It is also one of the most extensively studied in cancer and has been implicated in majority of human malignancies, including endometrial tumours (Anastas \& Moon 2012, Dellinger et al. 2012, van der Zee et al. 2013, Anastas 2015, Eskander et al. 2016). Wnt signalling mechanisms in the context of cancer have been extensively reviewed (Anastas \& Moon 2012,
Niehrs 2012, Humphries \& Mlodzik 2017, Kim et al. 2017, Schatoff et al. 2017, Tabatabai et al. 2017, Zhan et al. 2017).

Briefly, Wnt signalling comprises two distinct pathways, each with different ligands, coreceptors and functions. It is important to study both avenues, as considerable interplay and feedback exists between them. The canonical (or $\beta$-catenin dependent) Wnt signalling pathway is understood as governing proliferation and survival, achieved through accumulation of cytosolic $\beta$-catenin, which translocates to the nucleus, binding to transcription factors and activating downstream modulators. B-catenin accumulation is regulated by a 'destruction complex' consisting of APC, GSK3B and AXIN, which ubiquitinates $\beta$-catenin for degradation. Canonical ligands include WNT7, WNT3 and WNT10, which bind to FZD receptors.

Non-canonical (or $\beta$-catenin independent) Wnt signalling is linked to differentiation, cell polarity and migration (Simons \& Mlodzik 2008, Sato et al. 2010, Clark et al. 2012). This arm of Wnt can be further divided into Wnt/Calcium signalling and planar cell polarity (PCP) signalling, achieved via WNT5A activation of the tyrosine kinases ROR1, ROR2 and RYK. The non-canonical pathway has the ability to antagonise Wnt/ $\beta$-catenin activity. There is significant crosstalk and overlap between the Wnt signalling arms, with growing acceptance of a Wnt network theory (Grumolato et al. 2010, Kikuchi et al. 2011, Anastas 2015, Ford et al. 2016).

\section{Wnt in endometrial homeostasis}

In the female adult, the endometrium undergoes structural modification in response to hormonal fluctuations of the menstrual cycle; both glands and stroma proliferate under the influence of oestrogen (proliferative phase), while progesterone drives differentiation (secretory phase) (Fig. 1 panel A). Hormone depletion at menopause causes the endometrium to atrophy and thin, with a discontinuation of normal endometrial cycling and subsequent inactivity of Wnt signalling (Fig. 1 panel B). Hyperplasia (Fig. 1 panel C) and ultimately, cancer (Fig. 1 panel D) arise when this closely controlled cycle goes awry, with epidemiological data linking type one tumorigenesis and unopposed oestrogen exposure suggesting the same pathways are involved in both cyclical proliferation and neoplasia (Kaaks et al. 2002).

An early in vitro culture study of one endometrial cell line reported that mRNA expression of Wnt ligands was unaffected by hormone levels (Bui et al. 1997). However, it is now well documented that most components of 


\section{CANCER}

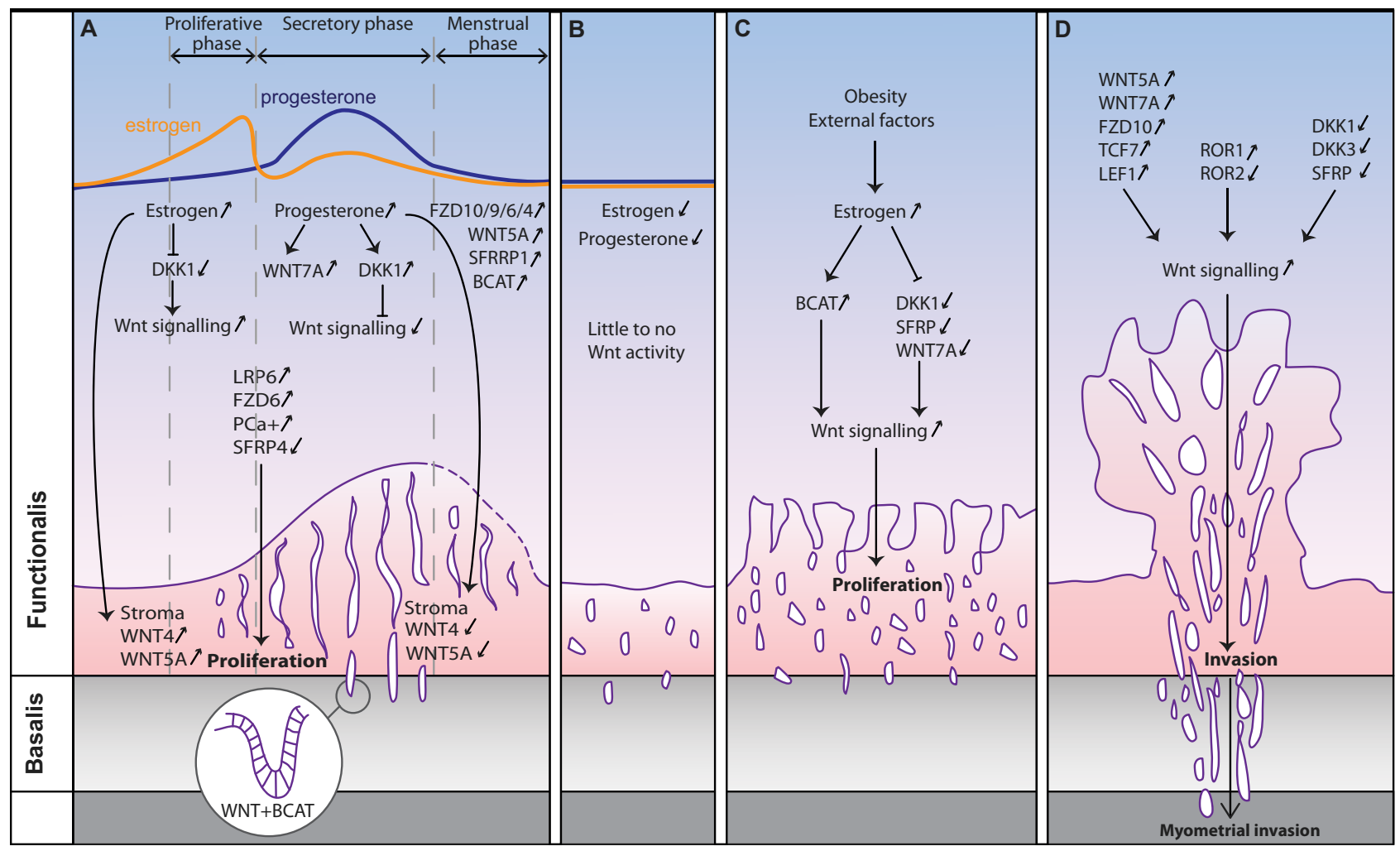

Figure 1

Tracking Wnt signalling across endometrium homeostasis, menopause and tumorigenesis. Wnt signalling plays a key role in the fluctuation between proliferative, secretory and menstrual endometrium which coincides with oestrogen (yellow) and progesterone (blue) regulation (Panel A). During menopause, hormone activity decreases and there is no functioning wnt signalling (Panel B). An increase in unopposed oestrogen arising from factors such as obesity, or beta-catenin mutations, can cause re activation of Wnt signalling resulting in a thickened endometrium and hyperplasia (Panel C). Continuing signalling with the addition of non-canonical components such as the ROR receptors allows for tumorigenesis and further invasion into the myometrium (Panel D). Layers of the endometrium include the functionalis (pink), basal (light grey) and myometrium (dark grey). A full colour version of this figure is available at https://doi.org/10.1530/ERC-18-0112.

the Wnt system are expressed in the physiological adult endometrium, and several studies have examined Wnt signalling's role in mediating the hormonally driven regenerative balance between proliferation and differentiation (Fig. 1 panel A). In a small gene expression and cell line study, Wang and colleagues (Wang et al. 2009) demonstrated a regulatory relationship between oestrogen, progesterone and Wnt signalling elements. Profiling and data set pathway analysis revealed significant downregulation of $\beta$-catenin signalling in early and midsecretory endometrium compared to proliferative tissue. Additionally, the Wnt inhibitor DKK1 was induced by progesterone and was elevated during the early secretory phase of the cycle, declining throughout the phase as supported by additional studies (Tulac et al. 2006). Earlier in vitro experiments by Oehler and colleagues (Oehler et al. 2002) showed that progesterone upregulated Wnt7a, suggesting a link between this ligand and the anti-proliferative effects of progesterone in the endometrium. Coordinated upregulation of WNT5A, FZD10/9/6/4, SFRP1 and $\beta$-catenin after progesterone inhibition in patient samples suggests an important mediator role for Wnt signalling in menstruation and tissue repair (Catalano et al. 2007). The relationship between the Wnt system and hormones has been extensively profiled in animal studies, where induction of the Wnt/ $\beta$-catenin pathway was shown to induce endometrial hyperplasia but was not sufficient, in isolation, to trigger neoplastic transformation (Katayama et al. 2006, Carmon \& Loose 2008, Satterfield et al. 2008, Jeong et al. 2009, Tanwar et al. 2009, Fan et al. 2012, van der Zee et al. 2013).

\section{Wnt and endometrial cancer}

A substantial body of literature spanning almost two decades has established a role for $\mathrm{Wnt} / \beta$-catenin signalling

\section{(C) 2018 Society for Endocrinology Published by Bioscientifica Ltd.} Printed in Great Britain 
in endometrial hyperplasia and cancer (Table 2), from the first limited study of 76 samples (Fukuchi et al. 1998) showing accumulation of $\beta$-catenin in $38 \%$ of endometrial cancers, to the TCGA's isolation of mutations in the $\beta$-catenin gene in $36.6 \%$ of 175 non-ultra-mutated endometrioid tumours. Estimates of the prevalence of activating mutations in $\beta$-catenin have varied depending on the study and methodology and not all have assessed the functional significance of these mutations by examining nuclear localisation of $\beta$-catenin or its correlation with clinicopathological features. Many of the immunohistochemistry studies have been on relatively small cohorts from a single clinical site and have focused on endometrioid endometrial cancers. Importantly, there has been no international study to date examining the role of $\mathrm{Wnt} / \beta$-catenin across a range of sites in different countries, to account for demographic influences given the significant role of obesity in pathogenesis of this disease. The more robust of the most recent estimates suggest $\beta$-catenin mutation occurs in $20-25 \%$ of endometrioid endometrial cancers (Byron et al. 2012, McConechy et al. 2014), while the more reliable - though dated - of the immunohistochemistry studies (Moreno-Bueno et al. 2002, Scholten et al. 2003) reported nuclear accumulation of $\beta$-catenin in $12-31 \%$ of endometrioid endometrial cancers. The only larger-scale study (Saegusa et al. 2001) to look at both nuclear accumulation and $\beta$-catenin mutations put the latter at $23 \%$ and the former at $28 \%$, concluding that the upper number was a more accurate reflection of prevalence. In a validation study comparing the TCGA dataset with large independent cohort, Liu and colleagues (Liu et al. 2013, 2014) showed overexpression in $\beta$-catenin-mutated tumours of Wnt pathway components including Wnt5a, Frizzled-10, TCF7 and LEF1, correlating this to decreased overall survival. Elegant studies in mice using lithium to mimic increased Wnt/ $\beta$-catenin signalling have shown increased atypical hyperplasia in the presence of oestrogen (Gunin et al. 2004) and a robust proliferative response in human endometrial xenografts (Polotsky et al. 2009).

Two immunohistochemical (IHC) studies have investigated the expression, in endometrial cancer, of the canonical ligand WNT7A, which was previously touched on as a progesterone-mediated component of

Table 2 Comparison of major studies examining Wnt/beta-catenin signalling in endometrial cancer.

\begin{tabular}{|c|c|c|}
\hline Study & Year & Findings \\
\hline Fukuchi & 1998 & beta-Catenin mutation 10/76 EC samples \\
\hline Nei & 1999 & $\begin{array}{l}\text { Moderate-strong beta-catenin staining nucleus in } \\
60 \% \text { of } 20 \mathrm{EH} \text { samples; } 30 \% \text { of ECs }\end{array}$ \\
\hline Mirabelli & 1999 & beta-Catenin mutations 13/29 EC samples \\
\hline Schlosshauer & 2000 & $6 / 32$ beta-catenin mutations \\
\hline Palacios & 2001 & Nuclear staining of beta-catenin $10 / 40$ EC samples \\
\hline Saegusa & 2001 & $\begin{array}{l}\text { Nuclear beta-catenin staining 55/199 EECs } \\
\text { beta-Catenin mutations } 16 / 70 \text { samples }\end{array}$ \\
\hline Schlosshauer & 2001 & Nuclear beta-catenin staining $8 / 17$ EECs \\
\hline Machin & 2002 & $\begin{array}{l}\text { beta-Catenin mutations in } 15 / 59 \mathrm{EECs}, 11 \text { of these } \\
\text { had Positive beta-catenin staining in the nucleus }\end{array}$ \\
\hline Moreno-Bueno & 2002 & $\begin{array}{l}\text { Nuclear beta-catenin } 31.2 \% \text { of } 128 \mathrm{EECs}, 3 \% \text { of } \\
33 \text { non-EECs }\end{array}$ \\
\hline Ashihara & 2002 & $\begin{array}{l}\text { Nuclear beta-catenin staining } 14 / 25 \mathrm{EH} \text { and } 12 / 20 \\
\text { ECs } \\
\text { beta catenin mutations in } 2 / 20\end{array}$ \\
\hline Scholten & 2003 & Nuclear staining beta-catenin 29/233 ECs \\
\hline Pijnenborg & 2004 & Nuclear staining beta-catenin 9/24 ECs \\
\hline Konopka & 2007 & 9/56 EECs beta-catenin mutations \\
\hline Byron & 2012 & beta-Catenin mutations 88/454 EECs \\
\hline Cancer Genome Atlas & 2013 & $\begin{array}{l}\text { beta-Catenin mutations in } 36.6 \% \text { of } 175 \text { non- } \\
\text { ultramutated ECs; } 52 \% \text { of } 90 \text { mss/copy number } \\
\text { low group }\end{array}$ \\
\hline Liu & 2014 & $\begin{array}{l}\text { beta-Catenin mutations in a subgroup of } 47 / 54 \\
\text { EECs in younger, obese patients }\end{array}$ \\
\hline McConechy & 2014 & $\begin{array}{l}\text { beta Catenin mutations in 76/307 EECs; (6/31 high } \\
\text { grade) }\end{array}$ \\
\hline
\end{tabular}

\section{Methods}

PCR and IHC from fresh surgical (54) or fixed (36) samples

IHC, Western blot, RT-PCR

PCR

PCR, Western blot

IHC

IHC, RT-PCR and Southern blot, PCR and sequencing analysis, Western blot $\mathrm{IHC}$

PCR, IHC

IHC, PCR, laser microdissection of focal tumour areas

IHC, PCR

IHC

IHC, MS-PCR (for e-cadherin and APC)

PCR

PCR (direct sequencing)

Exome, whole genome, RNA and miRNA, DNA methylation and copy number, reverse phase protein assays

Integrated analysis of 271 EEC cases in TCGA cohort. Validation in independent cohort of $184 \mathrm{EECs}$

Select exon capture sequencing on a gene panel

Mutation and bioinformatics analysis

$\mathrm{EC}$, endometrial cancer; $\mathrm{EEC}$, endometrioid endometrial cancer; $\mathrm{EH}$, endometrial hyperplasia. 
regular endometrial cycling. The first study found that WNT7A was overexpressed in endometrial tumours (63\% of patients) compared to benign controls $(4.7 \%$ of patients) and correlated high WNT7A expression with increased grade, myometrial invasion and worse overall survival (Liu et al. 2013). This was a large cohort analysis, featuring 335 patients. The second study demonstrated a decrease in WNT7A expression in endometrial cancer (expression in only $37 \%$ of 70 patients) when compared to benign samples (expression in $88 \%$ of 70 patients), and correlated loss of WNT7A to poor survival (Peng et al. 2012). The use of different antibodies to detect Wnt7 expression can significantly impact the outcome of IHC studies, as we previously noted in the case of another Wnt pathway member, ROR2 (Ma et al. 2017). Given that WNT7A is confined to the luminal epithelium in the physiological endometrium, where it increases during gland proliferation and is inhibited by progesterone in secretory transformation (Fan et al. 2012), this ligand would, theoretically, be seen at increased levels during unopposed oestrogen-driven tumorigenesis.

Compared with benign endometrium, studies have revealed a downregulation of the Wnt inhibitors Dickkopf3 (DKK3) and Dickkopf1 (DKK1) and the secreted frizzled-related proteins in endometrial cancer, with a stepwise reduction in DKK1 expression from intrauterine disease to extrauterine disease and distant metastases, and correlation with high-grade disease and a poor prognosis (Hrzenjak et al. 2004, Risinger et al. 2005, Yi et al. 2009, Di Domenico et al. 2011, Dellinger et al. 2012, Eskander et al. 2016). These studies have principally examined relatively small, heterogeneous (predominantly endometrioid endometrial cancer) cohorts $(n=14-50)$ from a single clinical site. In vitro, DKK1 knockdown by siRNA in the Ishikawa endometrial cancer cell line has been shown to increase cell invasion and migration (Yi et al. 2013). This is in keeping with studies showing Wnt (in particular, the signalling component glycogen synthase kinase 3-beta) is one of several pivotal pathways implicated in regulation of the morphogenetic process known as epithelial-tomesenchymal transformation (EMT). EMT is essential in embryonic development, wound healing and repair and, when activated in cancer, leads to a more invasive and metastatic phenotype (Taki et al. 2003, Nelson \& Nusse 2004, Bachelder et al. 2005, Lee et al. 2006, De Craene \& Berx 2013, Kanzawa et al. 2013).

While $\beta$-catenin dependent signalling has a documented role in endometrial cancer, little is known about non-canonical (also known as $\beta$-catenin independent) signalling and its potential therapeutic applications. Previous reviews on Wnt signalling in the endometrium and endometrial cancer have not addressed this arm of the pathway at all. Bui and colleagues (Bui et al. 1997) mapped expression of Wnt ligands in a limited cohort of four endometrial cancer cell lines and four tumour samples compared with benign epithelial and stromal controls and found statistically significant downregulation of Wnt 4 mRNA in the cell lines and tumours, as well as possible suppression of Wnt2, 3 and 5a mRNA. Both Wnt4 and Wnt5a act on the noncanonical pathway, and the latter has been shown to be overexpressed in cervical, aggressive basal-like breast and ovarian cancers, as well as omental metastases, suggesting that this ligand is involved in progression of gynaecological neoplasms (Jönsson et al. 2002, Dejmek et al. 2005, Klemm et al. 2011, Ford et al. 2014, Lin et al. 2014). siRNA knockdown of Wnt5a in ovarian cancer cell lines reduced proliferation, migration and invasion and promoted cell cycle arrest and apoptosis in a study by Chen and colleagues (Chen et al. 2013), while the addition of Wnt5a to ovarian cancer cells in vitro-enhanced motility and invasiveness in a separate study by Qi and collaborators (Qi et al. 2014). Similar effects have been shown in metastatic melanoma (Weeraratna et al. 2002). Wnt5a is of particular interest because it acts as both promoter and suppressor, depending on the cancer, and is capable of signalling via all three Wnt pathways (Chen et al. 2013, McDonald \& Silver 2009, Qian et al. 2007). In non-canonical signalling, Wnt5a binds to a family of receptors called receptor tyrosine kinase-like orphan receptors (RORs). RORs are emerging as an exciting area of inquiry in oncology due to their overexpression in a growing list of cancers, paucity in healthy adult tissues and location on the surface of cells (Ford et al. 2013).

\section{RORs and endometrial cancer}

ROR1 and ROR2 are transmembrane proteins of the receptor tyrosine kinase family first identified in a neuroblastoma cell line in 1992 (Masiakowski \& Carroll 1992). At that time they were dubbed 'orphan' receptors because their ligands were unknown, but RORs have since been linked to Wnt signalling in both development and disease (Green et al. 2008, 2014). Expressed at high levels during embryogenesis with roles in skeletal and neuronal development, the RORs are largely repressed in the adult. ROR1 is not expressed in vital organs such as brain, heart, lung or liver, however, has been found in regions of the parathyroid, pancreatic islets and gut (Balakrishnan et al. 2017). ROR2 expression in adult tissues has not been 
explicitly analysed, however, extrapolating from several studies, low expression of ROR2 may be found in adipose tissue, pancreas, thyroid, stomach, osteoblasts, precursor $\mathrm{B}$ cells, testis, lung, bladder, colon and - interestingly - the uterus, where its roles are yet to be elucidated (Al-Shawi et al. 2001, Matsuda et al. 2001, Yoda et al. 2003, Billiard et al. 2005, Baskar et al. 2008, Morioka et al. 2009, Cha et al. 2014). While extensive ROR1 analysis has been conducted in adult tissues, using a well-established antibody with no cross detection, such a process is yet to be undertaken for ROR2.

RORs bind Wnt5a and transduce PCP signalling. They have been shown to participate in cell migration and invasion, and cellular polarity - key tumorigenic properties - and are of interest in cancer because they tend to be associated with aggressive, poor prognosis disease (Morioka et al. 2009, O'Connell et al. 2010, Edris et al. 2012, Zhang et al. 2012a, 2014a, Ford et al. 2014, Henry et al. 2015, Henry et al. 2017). Aberrant ROR expression has been detected in a growing list of cancers, where it has been linked to growth, survival, motility and invasion, and where it correlates with more aggressive disease. Of note, ROR2 appears to have a dual oncogenic/suppressor role depending on the cancer and, hypothetically, whether it drives canonical or non-canonical Wnt signalling (Ford et al. 2016).

Only a handful of studies to date have specifically examined ROR expression in endometrial cancer, and an understanding of their role in this disease is limited. Firstly, for ROR1, a broad study of cell lines and tissue microarray using a monoclonal antibody specific for ROR1 (Zhang et al. 2012b), reported ROR1 expression in 28/29 (96\%) uterus cancer samples - the highest of any tissue studied, though data on tumour type or histology was not available. In the same study, 78/144 (54\%) of ovarian cancers stained moderately to strongly for ROR1, mostly clear cell, endometrioid and mucinous subtypes and expression was correlated with high-grade and less differentiated histology. Additionally, the authors found no detectable ROR1 expression on the 'normal' tissue counterparts. The other study examined ROR1 expression in 52 paraffin-fixed tumour samples (low stages, I-II) and blood from 26 endometrial cancer patients, correlating stronger expression to higher stage (Zhang et al. 2017). However, representative images from stage I and II ROR1 IHC both showed quite strong expression. Additionally, western blots representing ROR1 knockdown and overexpression in subsequent cell line models were not convincing. They used expression of C-Myc and CyclinD1 as downstream targets of ROR1, which are characterised as canonical, $\beta$-catenin Wnt targets (instead of RhoA and Rac) (Yu et al. 2017, Hasan et al. 2018) Extending this work in vitro and in a murine model, the authors found that transient overexpression of ROR1 in the Ishikawa and HEC1b cell lines increased tumour volume and weight, while ROR1 knockdown had the opposite effect.

Two studies have examined ROR2 broadly in endometrial cancer, but neither focused explicitly on this subject. The first investigated leiomyosarcoma, a rare nonepithelial endometrial tumour, which is clinically distinct from endometrial adenocarcinoma, as part of ROR2 screening in a host of soft tissue sarcomas (Edris et al. 2012), and the second largely extrapolated findings from endometrioid ovarian cancer on CD55-ROR2 signalling (Saygin et al. 2017).

The second ROR2 study, examining cancer stem cells in the endometrioid subtype of ovarian and endometrial cancers, reported a link to stemness and the complement protein CD55 mediated via ROR2-JNK signalling (Saygin et al. 2017). However, the majority of the experimental work in this study was performed on ovarian TOV112D and A2780 cell lines and the findings extrapolated to endometrioid endometrial cancer on the basis of CD55ROR2 immunoprecipitation in an endometrial model and levels of CD55 in the HEC1a cell line. (Saygin et al. 2017).

Our recent study investigated both ROR1 and ROR2 in a small clinical cohort of 77 endometrioid endometrial tumours and 10 serous endometrial tumours and identified distinct roles for these sister receptors (Henry et al. 2018). ROR2 overexpression correlated with better survival, and when silenced in the endometrial RL95-2 line, cells increased their ability to migrate and invade. It is worth noting the discovery of a potential tumour suppressor role for ROR2 in colorectal carcinogenesis, given the genetic link (clinically referred to as Lynch syndrome) between this cancer and some type one endometrioid endometrial tumours (Ma et al. 2016). By contrast, we found stronger ROR1 expression in the serous subtype of endometrial cancer, with silencing of this receptor in the KLE cell line decreasing migration and invasion. Future investigations should include larger cohorts, so that more patient data for less common subtypes such as serous can be analysed.

Given the potential overlap of genetic features and therapeutic paradigms between endometrial cancer and breast or ovarian tumours (Fadare et al. 2013, Levine \& The Cancer Genome Atlas Research Network 2013, Hoang et al. 2014), studies examining RORs in this context are of relevance. Several large-scale IHC studies (100-300 patients) have examined ROR expression in breast cancers (Zhang et al. 2012a, Henry et al. 2015, Chien et al. 2016). 
Of particular note due to the similarities between triplenegative breast cancer and serous endometrial tumours, Chien and colleagues (98) found a correlation between strong ROR1 staining in 47/210 samples of this breast tumour type and shorter disease-free, metastasis-free and overall survival. We previously (95) demonstrated ROR2 expression in 256/295 breast tumours and linked this to decreased disease-specific survival and lymphatic invasion. Knockdown studies by the authors in triplenegative breast cancer cell lines resulted in increased proliferation and migration, suggesting involvement of both $\beta$-catenin dependent and -independent signalling pathways. Studies (Zhang et al. 2012a, Chien et al. 2016) identified ROR1 expression as a feature of triple-negative breast cancer cell lines, and similar silencing studies resulted in reduced proliferation and increased apoptosis. ROR1 was also shown in breast adenocarcinomas to be linked to EMT-like gene signatures and higher rates of relapse and metastasis in a major study of 582 tissue microarray samples and 16 breast cancer cell lines (Cui et al. 2013). In serous ovarian cancer, both ROR1 and ROR2 have been demonstrated as overexpressed compared with benign controls. ROR1 has been correlated with diseasefree and overall survival and presence of metastases (Zhang et al. 2014a), stem cell-like gene signatures, higher rates of relapse and shorter median survival (Zhang et al. 2014b). In vitro, we have demonstrated (Henry et al. 2016) that overexpression of both RORs results in increased invasion, while their knockdown inhibits migration and invasion and sensitises chemotherapy resistant cell lines to cisplatin in ovarian cancer. In a cohort of 178 patient samples with matched benign, primary and metastatic lesions, both receptors were abnormally expressed in both epithelium and stroma - ROR2 most prominently in early stage, low-grade endometrioid ovarian tumours and in the stroma of the serous subtype (Henry et al. 2017). Therefore there is evidence for the potential of ROR1 and ROR2 as therapeutic targets in the related endometrial tumours.

In light of the established role for Wnt signalling in endometrial development, and median age of endometrial cancer diagnosis being 61 years (Hüsing et al. 2016), the effect of menopause on ROR1 and ROR2 expression warrants investigation. In our recent study of ROR1 and ROR2 (Henry et al. 2018), we did not have access to the menopause status of our patient cohort, but future studies should seek this information for both benign controls and cancer patients.

In sum, these findings indicate that ROR1 and ROR2 hold promise as prognostic markers and potential therapeutic targets in endometrial cancer, the most common gynaecological malignancy in the developed world and a growing problem as obesity rises.

\section{Targeting the Wnt pathway}

Current clinical trials which include endometrial cancer patients and targeted therapies are limited, as detailed in Table 2. Challenges documented with Wnt inhibitors in clinical trials include low recruitment (PRI-724 $\beta$-catenin inhibitor, NCT01302405 and Frizzled 10 inhibitor, NCT01469975), withdrawn funding (Wnt974, NCT02649530) and correction to dosage (RXC-004, NCT03447470). In Australia, there are no current Wnt therapies, but four endometrial-specific trials are underway for the use of immunotherapies, including a PD-L1 checkpoint inhibitor and a CTLA4 inhibitor. Although available for all advanced endometrial cancer patients eligible for chemotherapy, only POLE or MMRinstable tumour subtypes may respond. However, no study requires molecular screening for eligibility - the minimum is available blocks for MMR protein and PD-L1 IHC testing. A recent review of the PD-L1 inhibitor trials results from the KEYNOTE-028 study reported no benefit to patients if their PD-L1 IHC score was low (Kurnit \& Jazaeri 2017). Only two patients in the cohort exhibited POLE or MMR mutations, and both achieved a significant and partial response respectively. Therefore, for current immunotherapy trials in endometrial cancer to be successful, eligibility criteria should include screening for those with molecular subtypes which would respond best.

Globally, other endometrial cancer-targeted treatments are under phase I clinical trials, including ERK, VEGF and mTOR inhibitors. Interestingly there is only one study targeting the Wnt pathway that includes endometrial cancer patients: DKN01, a DKK1 inhibitor which actually restores active Wnt signalling. As previously discussed, DKK1 is reduced in endometrial cancer progression to invasive and metastatic disease, and the rationale to include endometrial cancer patients in a DKK1 inhibitor trial is, therefore, unclear. A controversial role for DKK1 and Wnt signalling in carcinogenesis was explored at length in a recent review (Kagey \& He 2017), but there was no evidence drawn from their analysis of the literature for DKK1 in endometrial cancer progression, and the review did not consider studies which found DKK1 downregulation. However, interesting conclusions were drawn on DKK1's role in alternative signalling pathways such as immune cell and tumour evasion. DKK1 can be released by cells of the tumour microenvironment, 
resulting in local immunosuppression. It may be important to analyse DKK1 across the molecular subtypes of endometrial cancer to better select patients for trial eligibility, as treating those with already-activated Wnt signalling may have unwanted side effects.

A number of small molecule canonical Wnt inhibitors are currently in phase I/II clinical trials for various cancer types, currently limited to tumours of the breast, colon and pancreas. If canonical Wnt signalling is indeed driving progression of endometrioid, type one tumours in approximately $30 \%$ of women with endometrial cancer, these trials could be extended to include these patients, with the caveat that targeting Wnt components can have unintended adverse effects via crosstalk to other parts of the network.
Wnt ligands are processed by the Porcupine protein before secretion, a key step in lipid modification and ligand-receptor binding activity. Therefore, to disrupt oncogenic Wnt signalling, a number of Porcupine inhibitors have been generated and are now in clinical trial (Table 1, LHK974, SMO9502, CGX1321, ETC-1922159). Porcupine modifications affect all Wnt ligands, irrespective of canonical or non-canonical signalling. Therefore, removal of all Wnt ligands in cancer cells may have unknown and undesired effects; for example in colorectal cancer, the non-canonical Wnt ligand ROR2 is methylated and silenced, allowing increased canonical $\beta$-catenin activity. When ROR2 is expressed and bound with Wnt5a in this context, feedback mechanisms result in canonical inhibition. If some

\section{$\beta$-catenin dependent signalling}

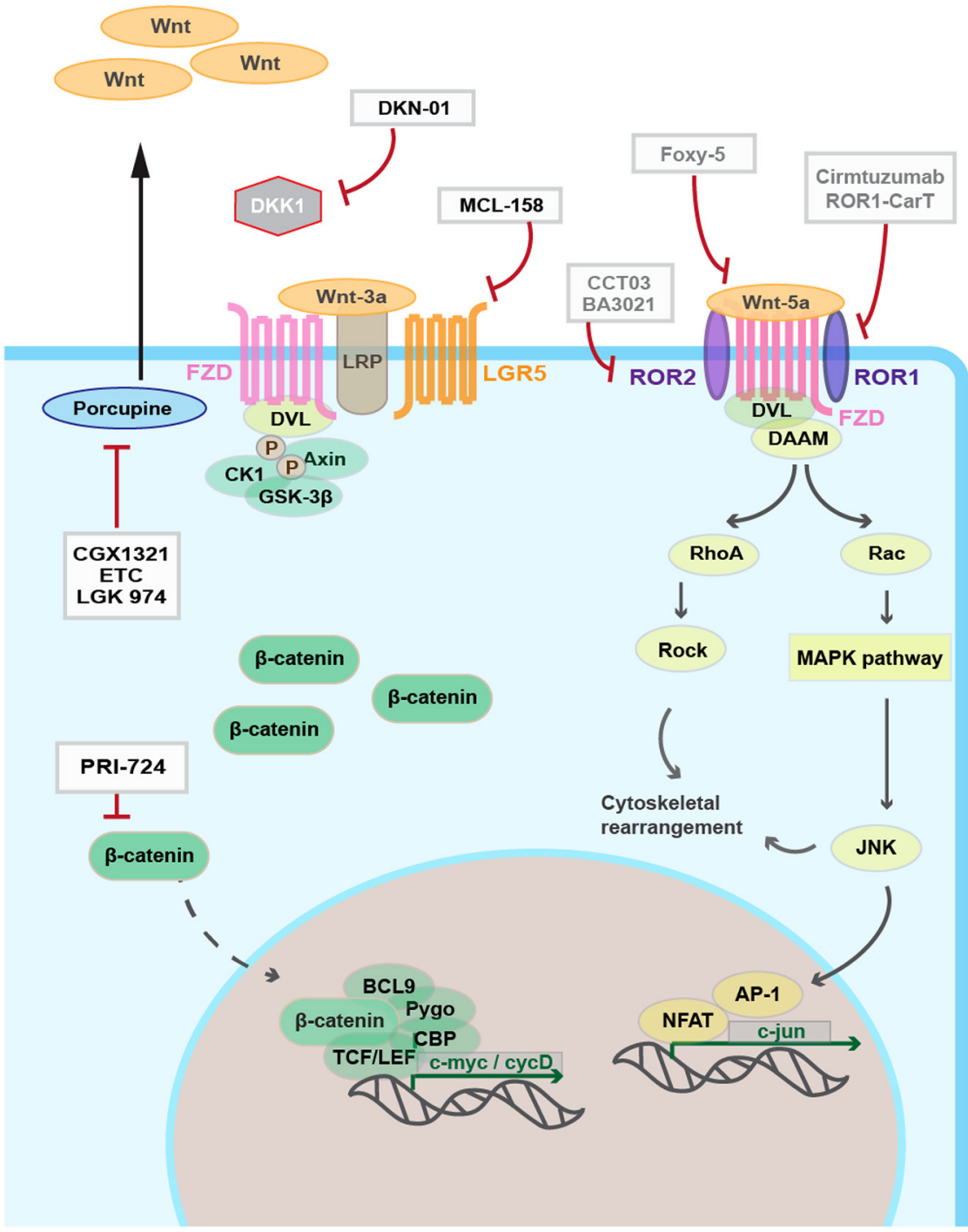

Figure 2

Current Wnt inhibitors in clinical trial. Inhibitors are shown in grey boxes with red arrows indicator target molecule. $\beta$-catenin-dependent signalling is shown on the left, while independent signalling through ROR1, ROR2 and Wnt5a is on the right. Drug compounds are listed in Table 3. A full colour version of this figure is available at https:// doi.org/10.1530/ERC-18-0112. 
subtypes of endometrial cancer are genetically similar to colorectal cancer, it follows that this mechanism may also apply, and removing all Wnt ligands may actually have an activating or unknown effect, necessitating caution with this approach.

RNF43 is a tumour suppresser that reduces Wnt frizzled receptor expression (Tsukiyama et al. 2015). It has been shown that those patients with RNF43 mutations and hyperactivated Wnt signalling have the greatest response to Porcupine inhibitors, meaning screening for patients with these characteristics may be key in anti-Porcupine clinical trials (Ho \& Keller 2015, Bhamra et al. 2017).

Because non-canonical Wnt signalling may have a more prominent role in the development of serous endometrial tumours, ROR-targeting therapies or Wnt5a inhibitors may be of most benefit to these patients. However, there is presently only one non-canonical ligand target drug in clinical trials: Foxy-5 (NCT02655952), a Wnt5a mimetic, which activates non-canonical signalling (Canesin et al. 2017). A dose-escalating study of Foxy-5 in breast, colon or prostate cancer patients was recently completed in mid-2017, but results are yet to be published. Pre-clinical in vivo models reported that Foxy-5 inhibited metastasis of prostate cancer cells without affecting tumour cell proliferation (Canesin et al. 2017). Foxy-5 was used on low-expressing Wnt5a tumour cells, with the theory that increased ROR2-Wnt5a signalling inhibits $\beta$-catenin activation of metastatic target genes (Ying et al. 2008). However, for the current Foxy-5 clinical trial, there is no inclusion or exclusion criteria to single out patients with low Wnt5a expression. As we and others have shown, Wnt5a can bind to both ROR1 and ROR2, initiating a multitude of complex downstream cascades, which may be involved in cancer progression, depending on tumour type (Weeraratna et al. 2002, Da Forno et al. 2008, Fukuda et al. 2008, Ren et al. 2011, Kanzawa et al. 2013, Ford et al. 2014, Qi et al. 2014, Hasan et al. 2018). In addition, recent work has demonstrated a role for two distinct Wnt5a isoforms, Wnt5a-short and Wnt5a-long, in colorectal cancer progression and active Wnt signalling (Huang et al. 2017). It is unknown what isoform Foxy-5 is based upon, and prudence is required, particularly for breast cancer patients where an increase of Wnt5a and ROR receptors has been shown to have oncogenic properties (Henry et al. 2015, Han et al. 2018, Kobayashi et al. 2018).

A number of therapies have entered development as evidence builds for the non-canonical receptors, ROR1 and 2 across tumour types. The most advanced of these is Cirmtuzumab, a first-in-class antibody that targets ROR1, which is presently in phase I/II trials in chronic lymphoid leukaemia (CLL; Choi et al. 2015) and breast cancer (NCT03420183, NCT02776917). In results that have only just come to press, this world-first ROR1-directed therapy demonstrated no dose-dependent toxicity, a long halflife and inhibition of stem cell-like expression signatures in CLL (Choi et al. 2018). Following this successful trial, a phase II study has commenced to investigate the efficacy of cirmtuzumab in combination with Ibrutinib (BTK inhibitor) in B-cell malignancies (NCT03088878).

In addition to cirmtuzumab, a number of other antiROR1 therapies are also in pre-clinical development

Table 3 Current clinical trials involving Wnt targets and/or endometrial cancer.

\begin{tabular}{|c|c|c|c|}
\hline Target & Drug & Clinical trial inclusion & Clinical trial ID \\
\hline \multicolumn{4}{|l|}{ Australia: Endometrial only } \\
\hline PD-L1 & Durvalumab & Advanced endometrial ca & ACTRN12617000106336 \\
\hline CTLA4 & AGEN1884 & Advanced endometrial ca & NCT03495882 \\
\hline PD-L1 & Rucaparib & Advanced endometrial ca & NCT03101280 \\
\hline PD-L1 & CBT-501 & Advanced endometrial ca & NCT03053466 \\
\hline mTOR & MLN0128 & Advanced endometrial ca & NCT02725268 \\
\hline \multicolumn{4}{|c|}{ USA/Europe: Endometrial only } \\
\hline ER & Fulvestrant & Recurrent, persistent or met endo ca & NCT00006903 \\
\hline MEK/ERK & Selumetinib & Recurrent, persistent or met endo ca & NCT01011933 \\
\hline VEGF & Cediranib & Recurrent, persistent or met endo ca & NCT01132820 \\
\hline $\mathrm{EZH} 2$ & Tazemetostat & Recurrent, persistent or met endo ca & NCT03348631 \\
\hline mTOR & Temsirolimus & Recurrent, persistent or met endo ca & NCT01068249 \\
\hline Multiple kinases & Nintedanib & Recurrent, persistent or met endo ca & NCT02730416 \\
\hline DKK1 & DKN-01 & Recurrent, persistent or met endo ca & NCT03395080 \\
\hline \multicolumn{4}{|l|}{ Wnt inhibitors } \\
\hline Porcupine inhibitor & LGK974 & $\begin{array}{l}\text { Pancreatic, colorectal, melanoma, TNBC, head and neck } \\
\text { SC, cervical SC, oesophageal SC, lung SC }\end{array}$ & NCT01351103 \\
\hline Unknown Wnt inhibitor & SM08502 & Advanced solid tumours & NCT03355066 \\
\hline
\end{tabular}

Ca, cancer; CLL, chronic lymphocytic leukaemia; Endo, endometrial; met, metastatic; SC, squamous cell; TNBC, triple-negative breast cancer. 
(Hojjat-Farsangi et al. 2017, Yin et al. 2017, Hassannia et al. 2018). Of these, ROR1 chimeric antigen receptor (CAR)-T cell therapy has attracted interest. CAR-T cell therapy involves gene transfer of receptors into $\mathrm{T}$ cells to induce cancer-specific immune responses. Because ROR1 is known to be expressed specifically on cancer cells, it is an attractive target for $\mathrm{T}$ cell therapy. In vivo models have shown positive responses to this type of therapy (Berger et al. 2015); however, of the two current phase I trials investigating toxicity of these methods, one was terminated due to unavailability of reagents and as it had no enrolments (NCT02194374). Recruitment is ongoing for the other, a basket design, dose-escalating study including ROR1-positive tumours such as breast cancer, lymphoma, leukaemia and lung cancer (NCT02706392). As we have demonstrated opposing roles for ROR1 and ROR2 in endometrial cancer (Henry et al. 2018), it will be critical to monitor the effect on ROR2, when targeting ROR1 in endometrial cancer.

Current Wnt-targeting therapies and which components of the pathway they target are shown in Fig. 2.

\section{Conclusion}

Despite its prevalence, endometrial cancer remains understudied and the dominant treatment paradigm entails significant morbidity. Advances on the molecular frontier could be life-changing for patients, and Wnt signalling may prove a fruitful avenue for targeted therapies. Further investigation into Wnt activity, internal signalling interactions, and what influence hormonal fluctuations and metabolic factors have on this complex but therapeutically promising signalling network is required in endometrial cancer, where treatments remain limited despite growing prominence due to obesity and childbearing later in life or not at all.

\section{Declaration of interest}

The authors declare that there is no conflict of interest that could be perceived as prejudicing the impartiality of this review.

\section{Funding}

This work did not receive any specific grant from any funding agency in the public, commercial or not-for-profit sector.

\section{Acknowledgements}

The authors would like to thank Eve Jary and Dr Kristina Warton for their feedback and suggestions on the manuscript and figures.

\section{References}

Al-Shawi R, Ashton SV, Underwood C \& Simons JP 2001 Expression of the Ror1 and Ror2 receptor tyrosine kinase genes during mouse development. Development Genes and Evolution 211 161-171. (https:// doi.org/10.1007/s004270100140)

AlHilli MM, Mariani A, Bakkum-Gamez JN, Dowdy SC, Weaver AL, Peethambaram PP, Keeney GL, Cliby WA \& Podratz KC 2014 Riskscoring models for individualized prediction of overall survival in low-grade and high-grade endometrial cancer. Gynecologic Oncology 133 485-493. (https://doi.org/10.1016/j. ygyno.2014.03.567)

Allen NE, Key TJ, Dossus L, Rinaldi S, Cust A, Lukanova A, Peeters PH, Onland-Moret NC, Lahmann PH, Berrino F, et al. 2008 Endogenous sex hormones and endometrial cancer risk in women in the European Prospective Investigation into Cancer and Nutrition (EPIC). Endocrine-Related Cancer 15 485-497. (https://doi. org/10.1677/ERC-07-0064)

Amant F, Moerman P, Neven P, Timmerman D, Van Limbergen E \& Vergote I 2005 Endometrial cancer. Lancet 366 491-505. (https://doi. org/10.1016/S0140-6736(05)67063-8)

Anastas JN 2015 Functional Crosstalk Between WNT Signaling and Tyrosine Kinase Signaling in Cancer. Seminars in Oncology 42 820-831. (https://doi.org/10.1053/j.seminoncol.2015.09.020)

Anastas JN \& Moon RT 2012 WNT signalling pathways as therapeutic targets in cancer. Nature Reviews Cancer 13 11. (https://doi. org/10.1038/nrc3419)

Bachelder RE, Yoon SO, Franci C, de Herreros AG \& Mercurio AM 2005 Glycogen synthase kinase-3 is an endogenous inhibitor of Snail transcription: implications for the epithelial-mesenchymal transition. Journal of Cell Biology 168 29-33. (https://doi.org/10.1083/ jcb.200409067)

Bakkum-Gamez JN, Mariani A, Dowdy SC, Weaver AL, McGree ME, Martin JR, Keeney GL, Jatoi A, Gostout BS \& Podratz KC 2014 Efficacy of contemporary chemotherapy in stage IIIC endometrial cancer: a histologic dichotomy. Gynecologic Oncology 132 578-584. (https://doi.org/10.1016/j.ygyno.2014.01.007)

Balakrishnan A, Goodpaster T, Randolph-Habecker J, Hoffstrom BG, Jalikis FG, Koch LK, Berger C, Kosasih PL, Rajan A, Sommermeyer D, et al. 2017 Analysis of ROR1 protein expression in human cancer and normal tissues. Clinical Cancer Research 23 3061-3071. (https:// doi.org/10.1158/1078-0432.CCR-16-2083)

Baskar S, Kwong KY, Hofer T, Levy JM, Kennedy MG, Lee E, Staudt LM, Wilson WH, Wiestner A \& Rader C 2008 Unique cell surface expression of receptor tyrosine kinase ROR1 in human B-cell chronic lymphocytic leukemia. Clinical Cancer Research 14 396-404. (https:// doi.org/10.1158/1078-0432.CCR-07-1823)

Berger C, Sommermeyer D, Hudecek M, Berger M, Balakrishnan A, Paszkiewicz PJ, Kosasih PL, Rader C \& Riddell SR 2015 Safety of targeting ROR1 in primates with chimeric antigen receptor-modified T cells. Cancer Immunology Research 3 206-216. (https://doi. org/10.1158/2326-6066.CIR-14-0163)

Bhamra I, Adams N, Armer R, Bingham M, McKeever H, Phillips C, Thompson B \& Woodcock S 2017 Novel porcupine (PORCN) inhibitor RXC004: evaluation in models of RNF43 loss of function cancers. Journal of Clinical Oncology 35 e14094-e14094. (https://doi. org/10.1200/JCO.2017.35.15_suppl.e14094)

Billiard J, Way DS, Seestaller-Wehr LM, Moran RA, Mangine A \& Bodine PV 2005 The orphan receptor tyrosine kinase Ror2 modulates canonical Wnt signaling in osteoblastic cells. Molecular Endocrinology 19 90-101. (https://doi.org/10.1210/me.2004-0153)

Bokhman JV 1983 Two pathogenetic types of endometrial carcinoma. Gynecologic Oncology 15 10-17. (https://doi.org/10.1016/00908258(83)90111-7)

Bradford LS, Rauh-Hain JA, Schorge J, Birrer MJ \& Dizon DS 2015 Advances in the management of recurrent endometrial cancer. http://erc.endocrinology-journals.org https://doi.org/10.1530/ERC-18-0112
(2) 2018 Society for Endocrinology Published by Bioscientifica Ltd. Printed in Great Britain 
American Journal of Clinical Oncology 38 206-212. (https://doi. org/10.1097/COC.0b013e31829a2974)

Brinton LA, Felix AS, McMeekin DS, Creasman WT, Sherman ME, Mutch D, Cohn DE, Walker JL, Moore RG, Downs LS, et al. 2013 Etiologic heterogeneity in endometrial cancer: evidence from a Gynecologic Oncology Group trial. Gynecologic Oncology 129 277-284. (https://doi.org/10.1016/j.ygyno.2013.02.023)

Bui TD, Zhang L, Rees MC, Bicknell R \& Harris AL 1997 Expression and hormone regulation of Wnt2, 3, 4, 5a, 7a, 7b and 10b in normal human endometrium and endometrial carcinoma. British Journal of Cancer 75 1131-1136. (https://doi.org/10.1038/bjc.1997.195)

Byron SA, Gartside M, Powell MA, Wellens CL, Gao F, Mutch DG, Goodfellow PJ \& Pollock PM 2012 FGFR2 point mutations in 466 endometrioid endometrial tumors: relationship with MSI, KRAS, PIK3CA, CTNNB1 mutations and clinicopathological features. PLoS ONE 7 e30801. (https://doi.org/10.1371/journal.pone.0030801)

Canesin G, Evans-Axelsson S, Hellsten R, Krzyzanowska A, Prasad CP, Bjartell A \& Andersson T 2017 Treatment with the WNT5Amimicking peptide Foxy-5 effectively reduces the metastatic spread of WNT5A-low prostate cancer cells in an orthotopic mouse model. PLOS ONE 12 e0184418. (https://doi.org/10.1371/journal. pone.0184418)

Carmon KS \& Loose DS 2008 Secreted frizzled-related protein 4 regulates two Wnt7a signaling pathways and inhibits proliferation in endometrial cancer cells. Molecular Cancer Research 6 1017-1028. (https://doi.org/10.1158/1541-7786.MCR-08-0039)

Catalano RD, Critchley HO, Heikinheimo O, Baird DT, Hapangama D, Sherwin JR, Charnock-Jones DS, Smith SK \& Sharkey AM 2007 Mifepristone induced progesterone withdrawal reveals novel regulatory pathways in human endometrium. Molecular Human Reproduction 13 641-654. (https://doi.org/10.1093/molehr/gam021)

Cha J, Bartos A, Park C, Sun X, Li Y, Cha SW, Ajima R, Ho HY, Yamaguchi TP \& Dey SK 2014 Appropriate crypt formation in the uterus for embryo homing and implantation requires Wnt5a-ROR signaling. Cell Reports 8 382-392. (https://doi.org/10.1016/j. celrep.2014.06.027)

Chen S, Wang J, Gou WF, Xiu YL, Zheng HC, Zong ZH, Takano Y \& Zhao Y 2013 The involvement of RhoA and Wnt-5a in the tumorigenesis and progression of ovarian epithelial carcinoma. International Journal of Molecular Sciences 14 24187-24199. (https:// doi.org/10.3390/ijms141224187)

Chien HP, Ueng SH, Chen SC, Chang YS, Lin YC, Lo YF, Chang HK, Chuang WY, Huang YT, Cheung YC, et al. 2016 Expression of ROR1 has prognostic significance in triple negative breast cancer. Virchows Archiv 468 589-595. (https://doi.org/10.1007/s00428-016-1911-3)

Choi MY, Widhopf GF 2nd, Ghia EM, Kidwell RL, Hasan MK, Yu J, Rassenti LZ, Chen L, Chen Y, Pittman E, et al. 2018 Phase I trial: cirmtuzumab inhibits ror1 signaling and stemness signatures in patients with chronic lymphocytic leukemia. Cell Stem Cell 22 951959.e953. (https://doi.org/10.1016/j.stem.2018.05.018)

Choi MY, Widhopf GF 2nd, Wu CC, Cui B, Lao F, Sadarangani A, Cavagnaro J, Prussak C, Carson DA, Jamieson C, et al. 2015 Preclinical Specificity and Safety of UC-961, a First-In-Class Monoclonal Antibody Targeting ROR1. Clinical Lymphoma, Myeloma and Leukemia 15 Suppl S167-S169. (https://doi.org/10.1016/j. clml.2015.02.010)

Church DN, Briggs SE, Palles C, Domingo E, Kearsey SJ, Grimes JM, Gorman M, Martin L, Howarth KM, Hodgson SV, et al. 2013 DNA polymerase epsilon and delta exonuclease domain mutations in endometrial cancer. Human Molecular Genetics 22 2820-2828. (https://doi.org/10.1093/hmg/ddt131)

Clark CE, Nourse CC \& Cooper HM 2012 The tangled web of noncanonical Wnt signalling in neural migration. Neurosignals 20 202-220. (https://doi.org/10.1159/000332153)

Cui B, Zhang S, Chen L, Yu J, Widhopf GF, 2nd, Fecteau JF, Rassenti LZ \& Kipps TJ 2013 Targeting ROR1 inhibits epithelial-mesenchymal transition and metastasis. Cancer Research 73 3649-3660. (https:// doi.org/10.1158/0008-5472.CAN-12-3832)

Da Forno PD, Pringle JH, Hutchinson P, Osborn J, Huang Q, Potter L, Hancox RA, Fletcher A \& Saldanha GS 2008 WNT5A expression increases during melanoma progression and correlates with outcome. Clinical Cancer Research 14 5825-5832. (https://doi. org/10.1158/1078-0432.CCR-07-5104)

De Craene B \& Berx G 2013 Regulatory networks defining EMT during cancer initiation and progression. Nature Reviews Cancer 13 97-110. (https://doi.org/10.1038/nrc3447)

de Haydu C, Black JD, Schwab CL, English DP \& Santin AD 2016 An update on the current pharmacotherapy for endometrial cancer. Expert Opinion on Pharmacotherapy 17 489-499. (https://doi.org/10.15 17/14656566.2016.1127351)

Dejmek J, Leandersson K, Manjer J, Bjartell A, Emdin SO, Vogel WF Landberg G \& Andersson T 2005 Expression and signaling activity of Wnt-5a/discoidin domain receptor-1 and Syk plays distinct but decisive roles in breast cancer patient survival. Clinical Cancer Research 11 520-528.

Dellinger TH \& Monk BJ 2009 Systemic therapy for recurrent endometrial cancer: a review of North American trials. Expert Review of Anticancer Therapy 9 905-916. (https://doi.org/10.1586/era.09.54)

Dellinger TH, Planutis K, Tewari KS \& Holcombe RF 2012 Role of canonical Wnt signaling in endometrial carcinogenesis. Expert Review of Anticancer Therapy 12 51-62. (https://doi.org/10.1586/era.11.194)

Di Domenico M, Santoro A, Ricciardi C, Iaccarino M, Iaccarino S, Freda M, Feola A, Sanguedolce F, Losito S, Pasquali D, et al. 2011 Epigenetic fingerprint in endometrial carcinogenesis: the hypothesis of a uterine field cancerization. Cancer Biology and Therapy 12 447-457. (https://doi.org/10.4161/cbt.12.5.15963)

Edris B, Espinosa I, Muhlenberg T, Mikels A, Lee CH, Steigen SE, Zhu S, Montgomery KD, Lazar AJ, Lev D, et al. 2012 ROR2 is a novel prognostic biomarker and a potential therapeutic target in leiomyosarcoma and gastrointestinal stromal tumour. Journal of Pathology 227 223-233. (https://doi.org/10.1002/path.3986)

Eritja N, Yeramian A, Chen B-J, Llobet-Navas D, Ortega E, Colas E, Abal M, Dolcet X, Reventos J \& Matias-Guiu X 2017 Endometrial carcinoma: specific targeted pathways. In Molecular Genetics of Endometrial Carcinoma, pp 149-207. Ed L Hedrick Ellenson. Berlin, Germany: Springer International Publishing. (https://doi. org/10.1007/978-3-319-43139-0_6)

Eskander RN, Ali S, Dellinger T, Lankes HA, Randall LM, Ramirez NC, Monk BJ, Walker JL, Eisenhauer E \& Hoang BH 2016 Expression patterns of the Wnt pathway inhibitors Dickkopf3 and secreted frizzled-related proteins 1 and 4 in endometrial endometrioid adenocarcinoma: an NRG oncology/gynecologic oncology group study. International Journal of Gynecological Cancer 26 125-132. (https://doi.org/10.1097/IGC.0000000000000563)

Fadare O, Gwin K, Desouki MM, Crispens MA, Jones HW 3rd, Khabele D, Liang SX, Zheng W, Mohammed K, Hecht JL, et al. 2013 The clinicopathologic significance of p53 and BAF-250a (ARID1A) expression in clear cell carcinoma of the endometrium. Modern Pathology 26 1101-1110. (https://doi.org/10.1038/ modpathol.2013.35)

Fan X, Krieg S, Hwang JY, Dhal S, Kuo CJ, Lasley BL, Brenner RM \& Nayak NR 2012 Dynamic regulation of Wnt7a expression in the primate endometrium: implications for postmenstrual regeneration and secretory transformation. Endocrinology 153 1063-1069. (https:// doi.org/10.1210/en.2011-1826)

Ferlay J, Soerjomataram I, Dikshit R, Eser S, Mathers C, Rebelo M, Parkin DM, Forman D \& Bray F 2015 Cancer incidence and mortality worldwide: sources, methods and major patterns in GLOBOCAN 2012. International Journal of Cancer 136 E359-E386. (https://doi.org/10.1002/ijc.29210)

Ford CE, Henry C, Llamosas E, Djordjevic A \& Hacker N 2016 Wnt signalling in gynaecological cancers: a future target for personalised 
medicine? Gynecologic Oncology 140 345-351. (https://doi. org/10.1016/j.ygyno.2015.09.085)

Ford CE, Punnia-Moorthy G, Henry CE, Llamosas E, Nixdorf S, Olivier J, Caduff R, Ward RL \& Heinzelmann-Schwarz V 2014 The non-canonical Wnt ligand, Wnt5a, is upregulated and associated with epithelial to mesenchymal transition in epithelial ovarian cancer. Gynecologic Oncology 134 338-345. (https://doi.org/10.1016/j.ygyno.2014.06.004)

Ford CE, Qian Ma SS, Quadir A \& Ward RL 2013 The dual role of the novel Wnt receptor tyrosine kinase, ROR2, in human carcinogenesis. International Journal of Cancer 133 779-787. (https://doi.org/10.1002/ ijc.27984)

Fukuchi T, Sakamoto M, Tsuda H, Maruyama K, Nozawa S \& Hirohashi S 1998 Beta-catenin mutation in carcinoma of the uterine endometrium. Cancer Research 58 3526-3528.

Fukuda T, Chen L, Endo T, Tang L, Lu D, Castro JE, Widhopf GF 2nd, Rassenti LZ, Cantwell MJ, Prussak CE, et al. 2008 Antisera induced by infusions of autologous Ad-CD154-leukemia B cells identify ROR1 as an oncofetal antigen and receptor for Wnt5a. PNAS $\mathbf{1 0 5}$ 3047-3052. (https://doi.org/10.1073/pnas.0712148105)

Grady D, Gebretsadik T, Kerlikowske K, Ernster V \& Petitti D 1995 Hormone replacement therapy and endometrial cancer risk: a metaanalysis. Obstetrics and Gynecology 85 304-313. (https://doi. org/10.1016/0029-7844(94)00383-O)

Green J, Nusse R \& van Amerongen R 2014 The role of Ryk and Ror receptor tyrosine kinases in Wnt signal transduction. Cold Spring Harbor Perspectives in Biology 6 a009175. (https://doi.org/10.1101/ cshperspect.a009175)

Green JL, Kuntz SG \& Sternberg PW 2008 Ror receptor tyrosine kinases: orphans no more. Trends in Cell Biology 18 536-544. (https://doi. org/10.1016/j.tcb.2008.08.006)

Group SGOCPECW, Burke WM, Orr J, Leitao M, Salom E, Gehrig P, Olawaiye AB, Brewer M, Boruta D, Herzog TJ, et al. 2014a Endometrial cancer: a review and current management strategies: part II. Gynecologic Oncology 134 393-402. (https://doi.org/10.1016/j. ygyno.2014.06.003)

Group SGOCPECW, Burke WM, Orr J, Leitao M, Salom E, Gehrig P, Olawaiye AB, Brewer M, Boruta D, Villella J, et al. 2014b Endometrial cancer: a review and current management strategies: part I. Gynecologic Oncology 134 385-392. (https://doi.org/10.1016/j. ygyno.2014.05.018)

Grumolato L, Liu G, Mong P, Mudbhary R, Biswas R, Arroyave R, Vijayakumar S, Economides AN \& Aaronson SA 2010 Canonical and noncanonical Wnts use a common mechanism to activate completely unrelated coreceptors. Genes and Development $\mathbf{2 4}$ 2517-2530. (https://doi.org/10.1101/gad.1957710)

Gunin AG, Emelianov VU, Mironkin IU, Morozov MP \& Tolmachev AS 2004 Lithium treatment enhances estradiol-induced proliferation and hyperplasia formation in the uterus of mice. European Journal of Obstetrics and Gynecology and Reproductive Biology 114 83-91. (https:// doi.org/10.1016/j.ejogrb.2003.09.023)

Han B, Zhou B, Qu Y, Gao B, Xu Y, Chung S, Tanaka H, Yang W, Giuliano AE \& Cui X 2018 FOXC1-induced non-canonical WNT5AMMP7 signaling regulates invasiveness in triple-negative breast cancer. Oncogene 37 1399-1408. (https://doi.org/10.1038/s41388-017-0021-2)

Hasan MK, Yu J, Widhopf GF 2nd, Rassenti LZ, Chen L, Shen Z, Briggs SP, Neuberg DS \& Kipps TJ 2018 Wnt5a induces ROR1 to recruit DOCK2 to activate Rac1/2 in chronic lymphocytic leukemia. Blood 132 170-178. (https://doi.org/10.1182/blood-2017-12-819383)

Hassannia H, Amiri MM, Jadidi-Niaragh F, Hosseini-Ghatar R, Khoshnoodi J, Sharifian R-A, Golsaz-Shirazi F, Jeddi-Tehrani M \& Shokri F 2018 Inhibition of tumor growth by mouse ROR1 specific antibody in a syngeneic mouse tumor model. Immunology Letters 193 35-41. (https://doi.org/10.1016/j.imlet.2017.11.010)

Henry C, Quadir A, Hawkins NJ, Jary E, Llamosas E, Kumar D, Daniels B, Ward RL \& Ford CE 2015 Expression of the novel Wnt receptor
ROR2 is increased in breast cancer and may regulate both betacatenin dependent and independent Wnt signalling. Journal of Cancer Research and Clinical Oncology 141 243-254. (https://doi. org/10.1007/s00432-014-1824-y)

Henry CE, Emmanuel C, Lambie N, Loo C, Kan B, Kennedy CJ, de Fazio A, Hacker NF \& Ford CE 2017 Distinct patterns of stromal and tumor expression of ROR1 and ROR2 in histological subtypes of epithelial ovarian cancer. Translational Oncology 10 346-356. (https:// doi.org/10.1016/j.tranon.2017.01.014)

Henry CE, Llamosas E, Daniels B, Coopes A, Tang K \& Ford CE 2018 ROR1 and ROR2 play distinct and opposing roles in endometrial cancer. Gynecologic Oncology 148 576-584. (https://doi.org/10.1016/j. ygyno.2018.01.025)

Henry CE, Llamosas E, Djordjevic A, Hacker NF \& Ford CE 2016 Migration and invasion is inhibited by silencing ROR1 and ROR2 in chemoresistant ovarian cancer. Oncogenesis 5 e226. (https://doi. org/10.1038/oncsis.2016.32)

Ho SY \& Keller TH 2015 The use of porcupine inhibitors to target Wntdriven cancers. Bioorganic and Medicinal Chemistry Letters 25 5472-5476. (https://doi.org/10.1016/j.bmcl.2015.10.032)

Hoang LN, Han G, McConechy M, Lau S, Chow C, Gilks CB, Huntsman DG, Kobel M \& Lee CH 2014 Immunohistochemical characterization of prototypical endometrial clear cell carcinoma diagnostic utility of HNF-1beta and oestrogen receptor. Histopathology 64 585-596. (https://doi.org/10.1111/his.12286)

Hojjat-Farsangi M, Daneshmanesh AH, Mozaffari F, Hansson L, Vågberg J, Byström S, Olsson E, Löfberg C, Norström CC \& Schultz J 2017 First-in-class oral small molecule against the tyrosine kinase ROR1 (KAN0439834) induced significant apoptosis of chronic lymphocytic leukemia cells. American Society of Hematology. (https:// doi.org/10.1038/s41375-018-0113-1)

Hrzenjak A, Tippl M, Kremser ML, Strohmeier B, Guelly C, Neumeister D, Lax S, Moinfar F, Tabrizi AD, Isadi-Moud N, et al. 2004 Inverse correlation of secreted frizzled-related protein 4 and beta-catenin expression in endometrial stromal sarcomas. Journal of Pathology 204 19-27. (https://doi.org/10.1002/path.1616)

Huang TC, Lee PT, Wu MH, Huang CC, Ko CY, Lee YC, Lin DY, Cheng YW \& Lee KH 2017 Distinct roles and differential expression levels of Wnt5a mRNA isoforms in colorectal cancer cells. PLOS ONE 12 e0181034. (https://doi.org/10.1371/journal. pone.0181034)

Humphries AC \& Mlodzik M 2017 From instruction to output: Wnt/PCP signaling in development and cancer. Current Opinion in Cell Biology 51 110-116. (https://doi.org/10.1016/j.ceb.2017.12.005)

Hüsing A, Dossus L, Ferrari P, Tjønneland A, Hansen L, Fagherazzi G, Baglietto L, Schock H, Chang-Claude J, Boeing H, et al. 2016 An epidemiological model for prediction of endometrial cancer risk in Europe. European Journal of Epidemiology 31 51-60. (https://doi. org/10.1007/s10654-015-0030-9)

Hussein YR, Weigelt B, Levine DA, Schoolmeester JK, Dao LN, Balzer BL, Liles G, Karlan B, Kobel M, Lee CH, et al. 2015 Clinicopathological analysis of endometrial carcinomas harboring somatic POLE exonuclease domain mutations. Modern Pathology 28 505-514. (https://doi.org/10.1038/modpathol.2014.143)

Jeong JW, Lee HS, Franco HL, Broaddus RR, Taketo MM, Tsai SY, Lydon JP \& DeMayo FJ 2009 beta-catenin mediates glandular formation and dysregulation of beta-catenin induces hyperplasia formation in the murine uterus. Oncogene 28 31-40. (https://doi. org/10.1038/onc.2008.363)

Jönsson M, Dejmek J, Bendahl P-O \& Andersson T 2002 Loss of Wnt-5a protein is associated with early relapse in invasive ductal breast carcinomas. Cancer Research 62 409-416.

Kaaks R, Lukanova A \& Kurzer MS 2002 Obesity, endogenous hormones, and endometrial cancer risk: a synthetic review. Cancer Epidemiology, Biomarkers and Prevention 11 1531-1543.
(2) 2018 Society for Endocrinology Published by Bioscientifica Ltd. Printed in Great Britain 
Kagey MH \& He X 2017 Rationale for targeting the Wnt signalling modulator Dickkopf-1 for oncology. British Journal of Pharmacology 174 4637-4650. (https://doi.org/10.1111/bph.13894)

Kanzawa M, Semba S, Hara S, Itoh T \& Yokozaki H 2013 WNT5A is a key regulator of the epithelial-mesenchymal transition and cancer stem cell properties in human gastric carcinoma cells. Pathobiology 80 235-244. (https://doi.org/10.1159/000346843)

Katayama S, Ashizawa K, Fukuhara T, Hiroyasu M, Tsuzuki Y, Tatemoto H, Nakada T \& Nagai K 2006 Differential expression patterns of Wnt and beta-catenin/TCF target genes in the uterus of immature female rats exposed to 17alpha-ethynyl estradiol. Toxicological Sciences 91 419-430. (https://doi.org/10.1093/toxsci/ kfj167)

Katoh M \& Katoh M 2017 Molecular genetics and targeted therapy of WNT-related human diseases (Review). International Journal of Molecular Medicine 40 587-606. (https://doi.org/10.3892/ ijmm.2017.3071)

Kiewisz J, Wasniewski T \& Kmiec Z 2015 Participation of WNT and betacatenin in physiological and pathological endometrial changes: association with angiogenesis. BioMed Research International 2015 854056. (https://doi.org/10.1155/2015/854056)

Kikuchi A, Yamamoto H, Sato A \& Matsumoto S 2011 New insights into the mechanism of Wnt signaling pathway activation. International Review of Cell and Molecular Biology 291 21-71. (https://doi. org/10.1016/B978-0-12-386035-4.00002-1)

Kim JH, Park SY, Jun Y, Kim JY \& Nam JS 2017 Roles of Wnt target genes in the journey of cancer stem cells. International Journal of Molecular Sciences 18 1604-1625. (https://doi.org/10.3390/ ijms18081604)

Klemm F, Bleckmann A, Siam L, Chuang HN, Rietkotter E, Behme D, Schulz M, Schaffrinski M, Schindler S, Trumper L, et al. 2011 betacatenin-independent WNT signaling in basal-like breast cancer and brain metastasis. Carcinogenesis 32 434-442. (https://doi.org/10.1093/ carcin/bgq269)

Kobayashi Y, Kadoya T, Amioka A, Hanaki H, Sasada S, Masumoto N, Yamamoto H, Arihiro K, Kikuchi A \& Okada M 2018 Wnt5a-induced cell migration is associated with the aggressiveness of estrogen receptor-positive breast cancer. Oncotarget 9 20979-20992. (https:// doi.org/10.18632/oncotarget.24761)

Kurnit KC \& Jazaeri AA 2017 Immunotherapy in endometrial cancer: who are the most appropriate patients? Translational Cancer Research S1132-S1135. (https://doi.org/10.21037/tcr.2017.08.26)

Lee JM, Dedhar S, Kalluri R \& Thompson EW 2006 The epithelialmesenchymal transition: new insights in signaling, development, and disease. Journal of Cell Biology 172 973-981. (https://doi. org/10.1083/jcb.200601018)

Levine DA \& The Cancer Genome Atlas Research Network 2013 Integrated genomic characterization of endometrial carcinoma. Nature 497 67. (https://doi.org/10.1038/nature12113)

Lin L, Liu Y, Zhao W, Sun B \& Chen Q 2014 Wnt5A expression is associated with the tumor metastasis and clinical survival in cervical cancer. International Journal of Clinical and Experimental Pathology $\mathbf{7}$ 6072-6078.

Liu Y, Meng F, Xu Y, Yang S, Xiao M, Chen X \& Lou G 2013 Overexpression of Wnt7a is associated with tumor progression and unfavorable prognosis in endometrial cancer. International Journal of Gynecological Cancer 23 304-311. (https://doi.org/10.1097/ IGC.0b013e31827c7708)

Liu Y, Patel L, Mills GB, Lu KH, Sood AK, Ding L, Kucherlapati R, Mardis ER, Levine DA, Shmulevich I, et al. 2014 Clinical significance of CTNNB1 mutation and Wnt pathway activation in endometrioid endometrial carcinoma. Journal of the National Cancer Institute $\mathbf{1 0 6}$ dju245. (https://doi.org/10.1093/jnci/dju245)

Ma SS, Henry CE, Llamosas E, Higgins R, Daniels B, Hesson LB, Hawkins NJ, Ward RL \& Ford CE 2017 Validation of specificity of antibodies for immunohistochemistry: the case of ROR2. Virchows Archiv 470 99-108. (https://doi.org/10.1007/s00428-016-2019-5)

Ma SS, Srivastava S, Llamosas E, Hawkins NJ, Hesson LB, Ward RL \& Ford CE 2016 ROR2 is epigenetically inactivated in the early stages of colorectal neoplasia and is associated with proliferation and migration. BMC Cancer 16 508. (https://doi.org/10.1186/s12885-0162576-7)

Markowska A, Pawałowska M, Lubin J \& Markowska J 2014 Signalling pathways in endometrial cancer. Contemporary Oncology 18 143-148. (https://doi.org/10.5114/wo.2014.43154)

Masiakowski P \& Carroll RD 1992 A novel family of cell surface receptors with tyrosine kinase-like domain. Journal of Biological Chemistry 267 26181-26190.

Matsuda T, Nomi M, Ikeya M, Kani S, Oishi I, Terashima T, Takada S \& Minami Y 2001 Expression of the receptor tyrosine kinase genes, Ror1 and Ror2, during mouse development. Mechanisms of Development $\mathbf{1 0 5}$ 153-156. (https://doi.org/10.1016/S0925-4773(01)00383-5)

McConechy MK, Ding J, Cheang MC, Wiegand K, Senz J, Tone A, Yang W, Prentice L, Tse K, Zeng T, et al. 2012 Use of mutation profiles to refine the classification of endometrial carcinomas. Journal of Pathology 228 20-30. (https://doi.org/10.1002/path.4056)

McConechy MK, Ding J, Senz J, Yang W, Melnyk N, Tone AA, Prentice LM, Wiegand K, McAlpine JN, Shah SP, et al. 2014 Ovarian and endometrial endometrioid carcinomas have distinct CTNNB1 and PTEN mutation profiles. Modern Pathology 27 128-134. (https:// doi.org/10.1038/modpathol.2013.107)

McDonald SL \& Silver A 2009 The opposing roles of Wnt-5a in cancer. British Journal of Cancer 101 209-214. (https://doi.org/10.1038/sj. bjc.6605174)

McPherson CP, Sellers TA, Potter JD, Bostick RM \& Folsom AR 1996 Reproductive factors and risk of endometrial cancer. The Iowa Women's Health Study. American Journal of Epidemiology 143 1195-1202. (https://doi.org/10.1093/oxfordjournals.aje.a008707)

Meng B, Hoang LN, McIntyre JB, Duggan MA, Nelson GS, Lee CH \& Kobel M 2014 POLE exonuclease domain mutation predicts long progression-free survival in grade 3 endometrioid carcinoma of the endometrium. Gynecologic Oncology 134 15-19. (https://doi. org/10.1016/j.ygyno.2014.05.006)

Moreno-Bueno G, Hardisson D, Sanchez C, Sarrio D, Cassia R, GarciaRostan G, Prat J, Guo M, Herman JG, Matias-Guiu X, et al. 2002 Abnormalities of the APC/beta-catenin pathway in endometrial cancer. Oncogene 21 7981-7990. (https://doi.org/10.1038/sj. onc.1205924)

Morioka K, Tanikawa C, Ochi K, Daigo Y, Katagiri T, Kawano H, Kawaguchi H, Myoui A, Yoshikawa H, Naka N, et al. 2009 Orphan receptor tyrosine kinase ROR2 as a potential therapeutic target for osteosarcoma. Cancer Science 100 1227-1233. (https://doi. org/10.1111/j.1349-7006.2009.01165.x)

Mota A, Colas E, Garcia-Sanz P, Campoy I, Rojo-Sebastian A, Gatius S, Garcia A, Chiva L, Alonso S, Gil-Moreno A, et al. 2017 Genetic analysis of uterine aspirates improves the diagnostic value and captures the intra-tumor heterogeneity of endometrial cancers. Modern Pathology 30 134-145. (https://doi.org/10.1038/ modpathol.2016.143)

Murali R, Soslow RA \& Weigelt B 2014 Classification of endometrial carcinoma: more than two types. Lancet Oncology 15 e268-e278. (https://doi.org/10.1016/S1470-2045(13)70591-6)

Nelson WJ \& Nusse R 2004 Convergence of Wnt, beta-catenin, and cadherin pathways. Science 303 1483-1487. (https://doi.org/10.1126/ science.1094291)

Niehrs C 2012 The complex world of WNT receptor signalling. Nature Reviews Molecular Cell Biology 13 767-779. (https://doi.org/10.1038/ nrm3470)

O'Connell MP, Fiori JL, Xu M, Carter AD, Frank BP, Camilli TC, French AD, Dissanayake SK, Indig FE, Bernier M, et al. 2010 The
(2) 2018 Society for Endocrinology Published by Bioscientifica Ltd. Printed in Great Britain 
orphan tyrosine kinase receptor, ROR2, mediates Wnt5A signaling in metastatic melanoma. Oncogene 29 34-44. (https://doi.org/10.1038/ onc.2009.305)

Obel JC, Friberg G \& Fleming GF 2006 Chemotherapy in endometrial cancer. Clinical Advances in Hematology and Oncology 4 459-468.

Oehler MK, MacKenzie IZ, Wallwiener D, Bicknell R \& Rees MC 2002 Wnt-7a is upregulated by norethisterone in human endometrial epithelial cells: a possible mechanism by which progestogens reduce the risk of estrogen-induced endometrial neoplasia. Cancer Letters 186 75-81. (https://doi.org/10.1016/S0304-3835(02)00259-8)

Peng C, Zhang X, Wang Y, Li L, Wang Q \& Zheng J 2012 Expression and prognostic significance of wnt7a in human endometrial carcinoma. Obstetrics and Gynecology International 2012 134962. (https://doi. org/10.1155/2012/134962)

Polotsky AJ, Zhu L, Santoro N \& Pollard JW 2009 Lithium chloride treatment induces epithelial cell proliferation in xenografted human endometrium. Human Reproduction 24 1960-1967. (https://doi. org/10.1093/humrep/dep115)

Qi H, Sun B, Zhao X, Du J, Gu Q, Liu Y, Cheng R \& Dong X 2014 Wnt5a promotes vasculogenic mimicry and epithelial-mesenchymal transition via protein kinase Calpha in epithelial ovarian cancer. Oncology Reports 32 771-779. (https://doi.org/10.3892/or.2014.3229)

Qian D, Jones C, Rzadzinska A, Mark S, Zhang X, Steel KP, Dai X \& Chen P 2007 Wnt5a functions in planar cell polarity regulation in mice. Developmental Biology 306 121-133. (https://doi.org/10.1016/j. ydbio.2007.03.011)

Ren D, Minami Y \& Nishita M 2011 Critical role of Wnt5a-Ror2 signaling in motility and invasiveness of carcinoma cells following Snail-mediated epithelial-mesenchymal transition. Genes Cells 16 304-315. (https://doi.org/10.1111/j.1365-2443.2011.01487.x)

Risinger JI, Maxwell GL, Chandramouli GV, Aprelikova O, Litzi T, Umar A, Berchuck A \& Barrett JC 2005 Gene expression profiling of microsatellite unstable and microsatellite stable endometrial cancers indicates distinct pathways of aberrant signaling. Cancer Research 65 5031-5037. (https://doi.org/10.1158/0008-5472.CAN04-0850)

Rutgers JK 2015 Update on pathology, staging and molecular pathology of endometrial (uterine corpus) adenocarcinoma. Future Oncology 11 3207-3218. (https://doi.org/10.2217/fon.15.262)

Saegusa M, Hashimura M, Yoshida T \& Okayasu I 2001 beta- Catenin mutations and aberrant nuclear expression during endometrial tumorigenesis. British Journal of Cancer 84 209-217. (https://doi. org/10.1054/bjoc.2000.1581)

Sato A, Yamamoto H, Sakane H, Koyama H \& Kikuchi A 2010 Wnt5a regulates distinct signalling pathways by binding to Frizzled2. EMBO Journal 29 41-54. (https://doi.org/10.1038/emboj.2009.322)

Satterfield MC, Song G, Hayashi K, Bazer FW \& Spencer TE 2008 Progesterone regulation of the endometrial WNT system in the ovine uterus. Reproduction, Fertility and Development 20 935-946. (https://doi.org/10.1071/RD08069)

Saygin C, Wiechert A, Rao VS, Alluri R, Connor E, Thiagarajan PS, Hale JS, Li Y, Chumakova A, Jarrar A, et al. 2017 CD55 regulates selfrenewal and cisplatin resistance in endometrioid tumors. Journal of Experimental Medicine 214 2715-2732. (https://doi.org/10.1084/ jem.20170438)

Schatoff EM, Leach BI \& Dow LE 2017 Wnt signaling and colorectal cancer. Current Colorectal Cancer Reports 13 101-110. (https://doi. org/10.1007/s11888-017-0354-9)

Scholten AN, Creutzberg CL, van den Broek LJ, Noordijk EM \& Smit VT 2003 Nuclear beta-catenin is a molecular feature of type I endometrial carcinoma. Journal of Pathology 201 460-465. (https:// doi.org/10.1002/path.1402)

Simons M \& Mlodzik M 2008 Planar cell polarity signaling: from fly development to human disease. Annual Review of Genetics 42 517-540. (https://doi.org/10.1146/annurev.genet.42.110807.091432)
Tabatabai R, Linhares Y, Bolos D, Mita M \& Mita A 2017 Targeting the Wnt pathway in cancer: a review of novel therapeutics. Targeted Oncology 12 623-641. (https://doi.org/10.1007/s11523-017-0507-4)

Taki M, Kamata N, Yokoyama K, Fujimoto R, Tsutsumi S \& Nagayama M 2003 Downregulation of Wnt4 and upregulation of Wnt5a expression by epithelialmesenchymal transition in human squamous carcinoma cells. Cancer Science 94 593-597. (https://doi. org/10.1111/j.1349-7006.2003.tb01488.x)

Talhouk A, McConechy MK, Leung S, Li-Chang HH, Kwon JS, Melnyk N, Yang W, Senz J, Boyd N, Karnezis AN, et al. 2015 A clinically applicable molecular-based classification for endometrial cancers. British Journal of Cancer 113 299-310. (https://doi.org/10.1038/ bjc.2015.190)

Tanwar PS, Lee HJ, Zhang L, Zukerberg LR, Taketo MM, Rueda BR \& Teixeira JM 2009 Constitutive activation of Beta-catenin in uterine stroma and smooth muscle leads to the development of mesenchymal tumors in mice. Biology of Reproduction 81 545-552. (https://doi.org/10.1095/biolreprod.108.075648)

Tsukiyama T, Fukui A, Terai S, Fujioka Y, Shinada K, Takahashi H, Yamaguchi TP, Ohba Y \& Hatakeyama S 2015 Molecular role of RNF43 in canonical and noncanonical Wnt signaling. Molecular and Cellular Biology 35 2007-2023. (https://doi.org/10.1128/MCB.00159-15)

Tulac S, Overgaard MT, Hamilton AE, Jumbe NL, Suchanek E \& Giudice LC 2006 Dickkopf-1, an inhibitor of Wnt signaling, is regulated by progesterone in human endometrial stromal cells. Journal of Clinical Endocrinology and Metabolism 91 1453-1461. (https://doi.org/10.1210/jc.2005-0769)

van der Zee M, Jia Y, Wang Y, Heijmans-Antonissen C, Ewing PC, Franken P, DeMayo FJ, Lydon JP, Burger CW, Fodde R, et al. 2013 Alterations in Wnt-beta-catenin and Pten signalling play distinct roles in endometrial cancer initiation and progression. Journal of Pathology 230 48-58. (https://doi.org/10.1002/path.4160)

Wang Y, Hanifi-Moghaddam P, Hanekamp EE, Kloosterboer HJ, Franken P, Veldscholte J, van Doorn HC, Ewing PC, Kim JJ, Grootegoed JA, et al. 2009 Progesterone inhibition of Wnt/betacatenin signaling in normal endometrium and endometrial cancer. Clinical Cancer Research 15 5784-5793. (https://doi. org/10.1158/1078-0432.CCR-09-0814)

Weeraratna AT, Jiang Y, Hostetter G, Rosenblatt K, Duray P, Bittner M \& Trent JM 2002 Wnt5a signaling directly affects cell motility and invasion of metastatic melanoma. Cancer Cell 1 279-288. (https:// doi.org/10.1016/S1535-6108(02)00045-4)

Yi N, Liao QP, Li T \& Xiong Y 2009 Novel expression profiles and invasiveness-related biology function of DKK1 in endometrial carcinoma. Oncology Reports 21 1421-1427.

Yi N, Liao QP, Li ZH, Xie BJ, Hu YH, Yi W \& Liu M 2013 RNA interference-mediated targeting of DKK1 gene expression in Ishikawa endometrial carcinoma cells causes increased tumor cell invasion and migration. Oncology Letters 6 756-762. (https://doi.org/10.3892/ ol.2013.1439)

Yin Z, Gao M, Chu S, Su Y, Ye C, Wang Y, Pan Z, Wang Z, Zhang H, Tong H, et al. 2017 Antitumor activity of a newly developed monoclonal antibody against ROR1 in ovarian cancer cells. Oncotarget 8 94210-94222. (https://doi.org/10.18632/ oncotarget.21618)

Ying J, Li H, Yu J, Ng KM, Poon FF, Wong SC, Chan AT, Sung JJ \& Tao Q 2008 WNT5A exhibits tumor-suppressive activity through antagonizing the Wnt/beta-catenin signaling, and is frequently methylated in colorectal cancer. Clinical Cancer Research 14 55-61. (https://doi.org/10.1158/1078-0432.CCR-07-1644)

Yoda A, Oishi I \& Minami Y 2003 Expression and function of the Rorfamily receptor tyrosine kinases during development: lessons from genetic analyses of nematodes, mice, and humans. Journal of Receptor and Signal Transduction Research 23 1-15. (https://doi.org/10.1081/ RRS-120018757)
2018 Society for Endocrinology Published by Bioscientifica Ltd. Printed in Great Britain 
Yu J, Chen L, Chen Y, Hasan MK, Ghia EM, Zhang L, Wu R, Rassenti LZ, Widhopf GF, Shen Z, et al. 2017 Wnt5a induces ROR1 to associate with 14-3-3zeta for enhanced chemotaxis and proliferation of chronic lymphocytic leukemia cells. Leukemia 31 2608-2614. (https://doi.org/10.1038/leu.2017.132)

Zhan T, Rindtorff N \& Boutros M 2017 Wnt signaling in cancer. Oncogene 36 1461-1473. (https://doi.org/10.1038/onc.2016.304)

Zhang H, Qiu J, Ye C, Yang D, Gao L, Su Y, Tang X, Xu N, Zhang D, Xiong L, et al. 2014a ROR1 expression correlated with poor clinical outcome in human ovarian cancer. Scientific Reports 4 5811. (https:// doi.org/10.1038/srep05811)

Zhang H YX, Ke J, Zhang Y, Dai C, Zhu M, Jiang F, Wan X 2017 ROR1 promotes the proliferation of endometrial cancer cells. International Journal of Clinical and Experimental Pathology 10 10603-10610.
Zhang S, Chen L, Cui B, Chuang H-Y, Yu J, Wang-Rodriguez J, Tang L, Chen G, Basak GW \& Kipps TJ 2012a ROR1 Is expressed in human breast cancer and associated with enhanced tumor-cell growth. PLOS ONE 7 e31127. (https://doi.org/10.1371/journal. pone.0031127)

Zhang S, Chen L, Wang-Rodriguez J, Zhang L, Cui B, Frankel W, Wu R \& Kipps TJ $2012 b$ The onco-embryonic antigen ROR1 is expressed by a variety of human cancers. American Journal of Pathology 181 1903-1910. (https://doi.org/10.1016/j.ajpath.2012.08.024)

Zhang S, Cui B, Lai H, Liu G, Ghia EM, Widhopf GF 2nd, Zhang Z, Wu CC, Chen L, Wu R, et al. 2014b Ovarian cancer stem cells express ROR1, which can be targeted for anti-cancer-stem-cell therapy. PNAS 111 17266-17271. (https://doi.org/10.1073/ pnas.1419599111)

Received in final form 31 August 2018

Accepted 6 August 2018

Accepted Preprint published online 8 August 2018
(C) 2018 Society for Endocrinology Published by Bioscientifica Ltd. Printed in Great Britain 